\title{
PENERAPAN ALGORITMA $K$-MEDOIDS UNTUK MENGELOMPOKKAN PENDUDUK 15 TAHUN KEATAS MENURUT LAPANGAN PEKERJAAN UTAMA
}

\author{
Nurliana Pulungan' ${ }^{1}$ Suhada $^{2}$, Dedi Suhendro ${ }^{3}$ \\ ${ }^{1}$ Mahasiswi Sistem Informasi STIKOM Tunas Bangsa Pematangsiantar, Indonesia \\ ${ }^{2,3}$ Dosen STIKOM Tunas Bangsa Pematangsiantar, Indonesia \\ Email: ${ }^{1}$ nurlianapulungan4@gmail.com, ${ }^{2}$ suhada.atb@gmail.com,
}

\begin{abstract}
Abstrak
Lapangan pekerjaan utama pada 15 tahun keatas hampir rata-rata tidak sesuai dengan usia mereka, yang seharusnya pekerjaan itu dilakukan orang dewasa tapi di lakukan oleh kalangan 15 tahun keatas. Maka dari itu saya melakukan pengelompokkan data pada penduduk 15 tahun ke atas agar kita mengetahui apa saja lapangan pekerjaan utama mereka. Disini saya menggunakan data mining dengan metode $K$-Medoids untuk mengelompokkan penduduk 15 tahun menurut Lapangan pekerjaan utama, penelitian ini dilakukan di Indonesia. Metode $K$-Medoids adalah metode dari data mining teknik partisi klasik clustering yang mengelompokkan dataset dari $\mathrm{n}$ objek ke dalam kelompok K dikenal apriori. Sebuah alat yang berguna untuk menentukan k adalah siluet. Hal ini lebih kuat untuk kebisingan dan outlier dibandingkan dengan K-Means karena meminimalkan sejumlah dissimilarities berpasangan bukannya jumlah kuadrat jarak euclidean. Sebuah medoid dapat didefinisikan sebagai objek cluster yang rata-rata perbedaan untuk semua objek dalam cluster minimal. Yaitu merupakan titik paling berlokasi di cluster. K-Medoids menggunakan objek pada kumpulan objek untuk mewakili sebuah cluster. Objek yang terpilih untuk mewakili sebuah cluster disebut medoid. Cluster dibangun dengan menghitung kedekatan yang dimiliki antara medoid dengan objek nonmedoid.
\end{abstract}

Kata Kunci: Data mining, K-Medoid, Lapangan Pekerjaan utama 15 tahun keatas.

\begin{abstract}
The main occupations in 15 years and above are on average not suitable for their age, which is done by adults but is done by people 15 years and older. Therefore, I do grouping data on population 15 years and above so that we know what their main jobs are. Here I use data mining with the K-Medoids method to classify the population of 15 years according to the main occupation, this research was conducted in Indonesia. The K-Medoids method is a method of collecting data with the classic clustering partitioning technique that groups datasets from $\mathrm{n}$ objects into $\mathrm{K}$ groups known a priori. A useful tool for determining $\mathrm{k}$ is a silhouette. It is stronger to be agreed upon and bigger than K-Means because it must add to the difference in the difference in the square of the euclidean distance. Attractions that can be determined as cluster objects are average differences for all objects in the cluster are minimal. That is the easiest point in the cluster. K-Medoids uses objects in a collection of objects to represent a cluster. The object chosen to represent a cluster is called medoid. Clusters are built by calculating the proximity they have between a medoid and nonmedoid objects.
\end{abstract}

Keywords: Data mining, K-Medoid, Main Job Fields 15 years and above

\section{PENDAHULUAN}

Pekerjaan merupakan hal yang penting di miliki oleh seseorang, karena kegiatan itu dapat menghasilkan kebutuhan mereka baik itu kebutuhan sekunder maupun kebutuhan primer. Bekerja bukan hanya sekedar memperoleh penghasilan dan mengejar kekayaan, akan tetapi dalam bekerja juga harus dilandasi dengan aturan yang ada dalam tempat bekerja. Bekerja membuat seseorang memperoleh suatu pengalaman, baik pengalaman manis maupun pengalaman pahit. Bekerja diartikan sebagai kegiatan ekonomi yang dilakukan oleh seseorang dengan maksud memperoleh atau membantu memperoleh pendapatan atau keuntungan, paling sedikit 1 jam (tidak terputus) dalam seminggu yang lalu. Kegiatan tersebut termasuk pola kegiatan pekerja tak dibayar yang membantu dalam suatu usaha/kegiatan ekonomi [1].

Ketika seseorang bekerja dia membutuhkan yang namanya lapangan pekerjaan untuk menunjang kreativitas maupun kemampuan yang di milikinya. Lapangan pekerjaan yang terbuka menimbulkan kebutuhan akan tenaga kerja. Kebutuhan tenaga kerja ini dibutuhkan oleh setiap perusahaan untuk melakukan kegiatan pekerjaan perusahaan tersebut pada tingkat upah, posisi (jabatan), dan syarat kerja tertentu. Namun, dalam hal ini menjadi persoalan yang terjadi di kehidupan penduduk, seperti masalah dalam pekerjaan. Pekerjaan untuk penduduk 15 tahun keatas menurut lapangan pekerjaan utamanya yang di terima terkadang tidak sesuai dengan yang terjadi dalam ukuran usia seseorang masyarakat tersebut. pekerjaan yang dilakukan sangatlah banyak baik itu di bagian perkantoraan maupun di lapangan.

Maka dari itu saya mencoba melakukan penelitian dan saya mengelompokkan data-data dengan menggunakan data mining metode $K$-Medoids Data mining adalah kegiatan menemukan pola yang menarik dari data dalam jumlah besar, data dapat disimpan dalam database, data warehouse, atau penyimpanan informasi lainnya. Data mining berkaitan dengan bidang ilmu - ilmu lain, seperti database system, data warehousing, statistik, machine learning, information retrieval, dan komputasi tingkat tinggi. Selain itu, data mining didukung oleh ilmu lain seperti neural network, pengenalan pola, spatial data analysis, image database, signal processing [2]. Teknik data mining digunakan untuk memeriksa basis data berukuran besar sebagai cara untuk menemukan pola yang baru dan berguna[3]. Dalam penelitian ini saya melihat rujukan dari beberapa jurnal yaitu, dilakukan oleh Triastuti Wuryandari, Agus Rusgiyono, Etik Setyowati dengan judul jurnal "Pengelompokan kabupaten/kota berdasarkan Komoditas pertanian menggunakan 
metode $K$-Medoids" mereka mengelompokkan data yang banyak dengan menggunakan metode $K$-medoids sehingga menghasilkan pengelompokkan berupa Produksi Padi, Jagung, Ubi Kayu,Ubi Jalar, Kedelai, Kacang Tanah, Kacang Hijau. Sehingga dengan cara ini dapat membuat pemerintah meningkatkan produksi [3].

Data mining adalah proses analitik yang dirancang untuk memeriksa sejumlah data yang besar dalam mencari suatu pengetahuan tersembunyi yang berharga dan konsisten [4]. Metode K-Medoids merupakan bagian dari partitioning clustering. Metode $K$-Medoids cukup efisien untuk dataset yang kecil. Langkah awal $K$-Medoids adalah mencari titik yang paling representatif (medoids) dalam sebuah dataset dengan menghitung jarak dalam kelompok dari semua kemungkinan kombinasi dari medoids sehingga jarak antar titik dalam suatu cluster kecil sedangkan jarak titik antar cluster besar [5].

Setelah data-data tersebut di kelompokkan dengan menggunakan data mining dengan metode K-Medoids maka, kita akan lebih mudah mengetahui lapangan pekerjaan utama pada 15 tahun ke atas. Berdasarkan latar belakang masalah di atas, maka penulis menganggkat judul "Penerapan Algoritma $K$-Medoids Untuk Mengelompokkan Penduduk 15 Tahun Keatas Menurut Lapangan Pekerjaan Utama”.

\section{TEORITIS}

\subsection{Metode Pengumpulan Data}

Dalam hal ini penulis memanfaatkan dokumentasi dan tulisan dari jurnal jurnal yang terdaulu serta Sumber data di peroleh dari badan pusat statistik nasional dengan situs https://www.bps.go.id. Data yang di gunakan dalam penelitian ini adalah data penduduk 15 tahun ke atas menurut lapangan pekerjaan utama dari tahun 2011-2018 yang terdiri dari 17 pekerjaan. Variable yang di gunakan adalah lapangan pekerjaan utama yang sudah di akumulasikan.

\subsection{Algoritma $K$-Medoids}

$K$-medoids tidak menentukan nilai rata-rata dari objek dalam cluster sebagai titik acuan, tapi menggunakan medoids (median), yang merupakan objek yang paling terletak dipusat sebuah cluster. Dengan demikian, metode partisi masih dapat dilakukan berdasarkan prinsip meminimalkan jumlah dari ketidak samaan antara setiap objek dan titik acuan yang sesuai (medoids). Penelitian ini dilakukan untuk mengetahui kelompok lapangan pekerjaan utama dengan dua cluster yaitu, cluster tinggi dan cluster rendah.

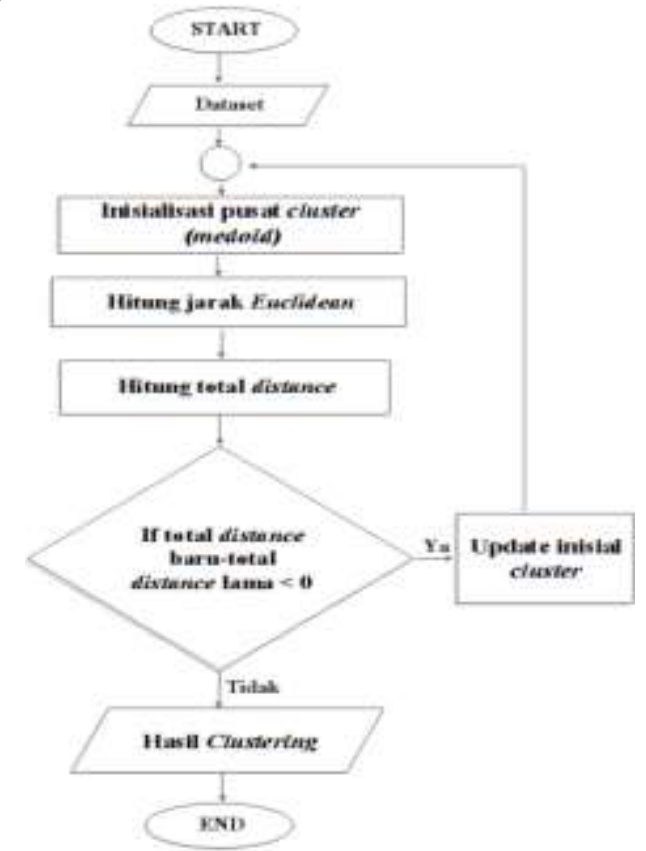

Gambar 1. Flowchart Metode K-Medoids Clustering

Berdasarkan gambar 1 dapat dijelaskan bahwa langkah-langkah metode $k$-medoids clustering diantaranya:

1. Inisialisasi pusat cluster sebanyak $k$ (jumlah cluster)

2. Alokasikan setiap data (objek) ke cluster terdekat menggunakan persamaan ukuran jarak Euclidian Distance dengan persamaan:

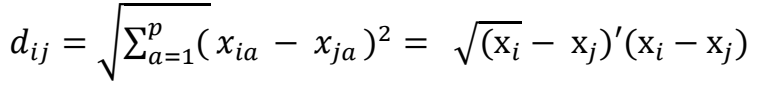

dimana $i=1, \ldots \ldots, n ; j=1, \ldots . ., n$ dan $p$ adalah banyak variable, serta $\mathrm{V}$ adalah matrik varian kovarian.

3. Pilih secara acak objek pada masing-masing cluster sebagai kandidat medoid baru.

4. Hitung jarak setiap objek yang berada pada masing-masing cluster dengan kandidat medoid baru. 
5. Hitung total simpangan (S) dengan menghitung nilai total distance baru - total distance lama. Jika $\mathrm{S}<0$, maka tukar objek dengan data cluster untuk membentuk sekumpulan $k$ objek baru sebagai medoid.

6. Ulangi langkah 3 sampai 5 hingga tidak terjadi perubahan medoid, sehingga didapatkan cluster beserta anggota cluster masing-masing.

\section{ANALISA DAN PEMBAHASAN}

\subsection{Penerapan Metode K-Medoids}

Pada tahapan ini pengolahan data lapangan pekerjaan utama menurut jenis pekerjaannya di indonesia mengggunakan algoritma $K$-Medoids. Berikut data lapangan pekerjaan utama menurut jenis pekerjaannya yang di ambil penulis melalui situs badan pusat statistik Nasional. Lagkah-langkah dalam menyelesaikan perhitungan manual data mining menggunakan $K$-Medoids clustering sebagai berikut:

1. Inisialisasi pusat cluster sebanyak 2 cluster dari data sample

Untuk pemilihan setiap medoid dipilih secara acak (random) di asumsikan pertanian, perhutanan dan perikanan dan kontruksi sebagai medoid awal.

Tabel 1. Medoid Awal

\begin{tabular}{|c|c|c|c|c|}
\hline Nama & 2011 & 2012 & 2013 & 2014 \\
\hline $\begin{array}{l}\text { Pertanian, Kehutanan dan } \\
\text { Perikanan }\end{array}$ & 40.773 .140 & 40.628 .841 & 39.992 .491 & 39.904 .349 \\
\hline Konstruksi & 5.954 .459 & 6.499 .654 & 6.651 .158 & 7.246 .027 \\
\hline \multicolumn{5}{|c|}{ Tabel 2. Lanjutan Medoids Awal } \\
\hline Nama & 2015 & 2016 & 2017 & 2018 \\
\hline $\begin{array}{l}\text { Pertanian, Kehutanan, } \\
\text { dan perikanan }\end{array}$ & 38.936 .567 & 38.034 .912 & 37.804 .198 & 38.700 .530 \\
\hline Konstruksi & 7.961 .235 & 7.842 .932 & 7.649 .802 & 7.058 .350 \\
\hline
\end{tabular}

2. Menghitung nilai jarak terdekat (cost) dengan persamaan eunclidian distance. Untuk menghitung jarak antara titik tiap objek menggunakan eunclidian distance. Rumus untuk menghitung jarak menggunakan persamaan (2.1). maka perhitungan untuk menghitung jarak setiap objek dengan medoid awal adalah sebagai berikut :

$$
D_{1} C_{1}=\sqrt{\begin{array}{l}
\left((40.773 .140-40.773 .140)^{2}+(40.628 .841-40.628 .841)^{2}\right) \\
+(39.992 .491-39.992 .491)^{2}+(39.904 .349-39.904 .349)^{2} \\
+(38.936 .567-38.936 .567)^{2}+(38.034 .912-38.034 .912)^{2} \\
+(37.804 .198-37.804 .198)^{2}+(38.700 .530-38.700 .530)^{2}
\end{array}}=0
$$

Hasil keseluruhan dapat dilihat pada tabel 3 sebagai berikut:

Tabel 3. Hasil perhitungan Algoritma K-Medoids iterasi ke-1

\begin{tabular}{clcc}
\hline No & \multicolumn{1}{c}{ Lapangan Pekerjaan Utama } & C1 & C2 \\
\hline 1 & Pertanian, Kehutanan dan Perikanan & 0 & 91.306 .596 \\
2 & Pertambangan dan Penggalian & 107.250 .727 & 16.149 .709 \\
3 & Industri Pengolahan & 66.051 .243 & 25.482 .432 \\
4 & Pengadaan Listrik, Gas, Uap/Air Panas dan Udara Dingin & 110.637 .043 & 19.491 .470 \\
5 & Pengadaan Air, Pengelolaan Sampah dan Daur Ulang, Pembuangan & 110.588 .081 & 19.431 .993 \\
& dan Pembersihan Limbah dan Sampah & & \\
6 & Konstruksi & 91.306 .596 & 0 \\
7 & Perdagangan Besar Dan Eceran; Reparasi dan Perawatan Mobil & 50.061 .951 & 41.583 .404 \\
& dan Sepeda Motor & & \\
8 & Transportasi dan Pergudangan & 97.834 .953 & 6.828 .018 \\
9 & Penyediaan Akomodasi dan Penyediaan Makan Minum & 96.144 .612 & 5.808 .493 \\
10 & Informasi dan Komunikasi & 109.376 .388 & 18.242 .645 \\
11 & Jasa Keuangan dan Asuransi & 106.885 .740 & 15.704 .705 \\
12 & Real Estate & 110.614 .199 & 19.459 .305 \\
13 & Jasa Perusahaan & 107.508 .333 & 16.339 .512 \\
14 & Administrasi Pemerintahan, Pertahanan dan Jaminan Sosial Wajib & 99.255 .601 & 8.189 .128 \\
15 & Jasa Pendidikan & 95.296 .291 & 4.230 .355 \\
16 & Jasa Kesehatan dan Kegiatan Sosial & 107.012 .369 & 15.840 .096 \\
17 & Jasa Lainnya & 95.097 .464 & 4.232 .382 \\
& & 1.560 .921 .591 & 328.320 .243 \\
\hline
\end{tabular}


Setelah di dapatkan hasil jarak dari setiap objek (cost) pada iterasi ke-1 maka lanjut ke iterasi ke-2. Kandidat medoid baru (non-medoid) pada iterasi ke-2 dapat dilihat pada tabel 4. dan 5. berikut:

Tabel 4. Medoid baru (Non-Medoid) iterasi ke-2

\begin{tabular}{|c|c|c|c|c|c|}
\hline \multicolumn{2}{|l|}{ Nama } & 2011 & 2012 & 2013 & 2014 \\
\hline \multicolumn{2}{|l|}{ Pertambangan dan Penggalian } & 1.396 .490 & 1.608 .091 & 1.489 .964 & 1.529 .045 \\
\hline \multicolumn{2}{|c|}{ Pengadaan Listrik, Gas, Uap/Air Panas dan Udara Dingin } & 177.570 & 225.484 & 205.779 & 233.399 \\
\hline \multicolumn{6}{|c|}{ Tabel 5. Lanjutan Medoid baru (Non-Medoid) iterasi ke-2 } \\
\hline Nama & 2015 & 2016 & \multicolumn{2}{|c|}{2017} & 2018 \\
\hline \multirow{2}{*}{$\begin{array}{l}\text { Pertambangan dan Penggalian } \\
\text { Pengadaan Listrik, Gas, Uap/Air Panas } \\
\text { dan Udara Dingin }\end{array}$} & 1.365 .067 & 1.387 .737 & \multicolumn{2}{|c|}{1.372 .382} & 1.383 .508 \\
\hline & 212.413 & 271.090 & \multicolumn{2}{|c|}{301.355} & 343.948 \\
\hline
\end{tabular}

Hitung kembali jarak setiap objek pada iterasi ke-2 dengan menggunakan medoid baru pada tabel 4. dan 5 berikut:

$$
D_{1} C_{1}=\sqrt{\begin{array}{l}
\left((40.773 .140-1.396 .490)^{2}+(40.628 .841-1.608 .091)^{2}\right) \\
+(39.992 .491-1.489 .964)^{2}+(39.904 .349-1.529 .045)^{2} \\
+(38.936 .567-1.365 .067)^{2}+(38.034 .912-1.387 .737)^{2} \\
+(37.804 .198-1.372 .382)^{2}+(38.700 .530-1.383 .508)^{2}
\end{array}}=107.250 .727
$$

Maka didapatkan hasil keseluruhannya dari iterasi ke-2 dapat dilihat dari tabel 6 sebagai berikut:

Tabel 6. Hasil Perhitungan Algoritma K-Medoids Iterasi ke-2

\begin{tabular}{|c|c|c|}
\hline \multirow[t]{2}{*}{ Lapangan Pekerjaan Utama } & \multicolumn{2}{|c|}{ Jarak ke Medoids } \\
\hline & C1 & $\mathrm{C2}$ \\
\hline Pertanian, Kehutanan dan Perikanan & 107.250 .727 & 110.637 .043 \\
\hline Pertambangan dan Penggalian & 0 & 3.395 .364 \\
\hline Industri Pengolahan & 41.508 .994 & 44.864 .960 \\
\hline Pengadaan Listrik, Gas, Uap/Air Panas dan Udara Dingin & 3.395 .364 & 0 \\
\hline $\begin{array}{l}\text { Pengadaan Air, Pengelolaan Sampah dan Daur Ulang, Pembuangan dan } \\
\text { Pembersihan Limbah dan Sampah }\end{array}$ & 3.360 .747 & 164.103 \\
\hline Konstruksi & 16.149 .709 & 19.491 .470 \\
\hline $\begin{array}{l}\text { Perdagangan Besar Dan Eceran; Reparasi dan Perawatan Mobil dan } \\
\text { Sepeda Motor }\end{array}$ & 57.650 .795 & 61.011 .652 \\
\hline Transportasi dan Pergudangan & 9.456 .787 & 12.820 .824 \\
\hline Penyediaan Akomodasi dan Penyediaan Makan Minum & 12.003.186 & 15.153 .840 \\
\hline Informasi dan Komunikasi & 2.194 .629 & 1.302 .361 \\
\hline Jasa Keuangan dan Asuransi & 769.139 & 3.792 .130 \\
\hline Real Estate & 3.374 .984 & 135.712 \\
\hline Jasa Perusahaan & 680.712 & 3.160 .649 \\
\hline Administrasi Pemerintahan, Pertahanan dan Jaminan Sosial Wajib & 8.227 .025 & 11.517 .127 \\
\hline Jasa Pendidikan & 12.075 .328 & 15.419 .287 \\
\hline Jasa Kesehatan dan Kegiatan Sosial & 943.177 & 3.694 .153 \\
\hline Jasa Lainnya & 12.208 .877 & 15.575 .871 \\
\hline Jumlah & 291.250 .177 & 322.136 .547 \\
\hline Total Cost & \multicolumn{2}{|c|}{613.386 .724} \\
\hline
\end{tabular}

4. Hitung Total Simpangan (S)

Setelah di dapatkan hasil nilai jarak iterasi ke-1 dan iterasi ke-2, hitung total simpangan (S) dengan mencari selisih dari total cost baru nilai total cost lama. Dengan ketentuan jika $\mathrm{S}<0$, maka tukar nilai objek dengan menentukan medoid baru.

$\mathrm{S}=$ Total $\cos t$ baru - Total cost lama

$=613.386 .724-1.889 .241 .834$

$=-1.275 .855 .110$

5. Ulangi langkah sebelumnya hingga $\mathrm{S}>0$, sehingga di dapatkan cluster beserta anggota cluster masing-masing. Setelah di dapatkan hasil nilai jarak iterasi ke-3, hitung total simpangan (S) dengan mencari selisih dari nilai total cost baru - nilai total cost lama. Dengan ketentuan jika $\mathrm{S}<0$, maka tukar nilai objek dengan menentukan medoid baru.

$$
\begin{aligned}
\mathrm{S} & =\text { Total cost } \text { baru }- \text { Total cost lama } \\
& =1.110 .791 .850-1.889 .241 .834 \\
& =497.405 .126
\end{aligned}
$$


Dengan nilai $\mathrm{S}>0$ proses cluster di hentikan, sehingga di peroleh anggota tiap cluster

\section{IMPLEMENTASI}

Pada tahap ini akan menampilkan hasil akhir serta langkah terakhir dalam penggunaan tools rapidminer 5.3. ini. Hasil yang akan di tampilkan adalah berupa pengelompokkan dimana hasil pengujian data akan tampak cluster dengan masing-masing anggota. Tampak pada gambar 2 berikut:

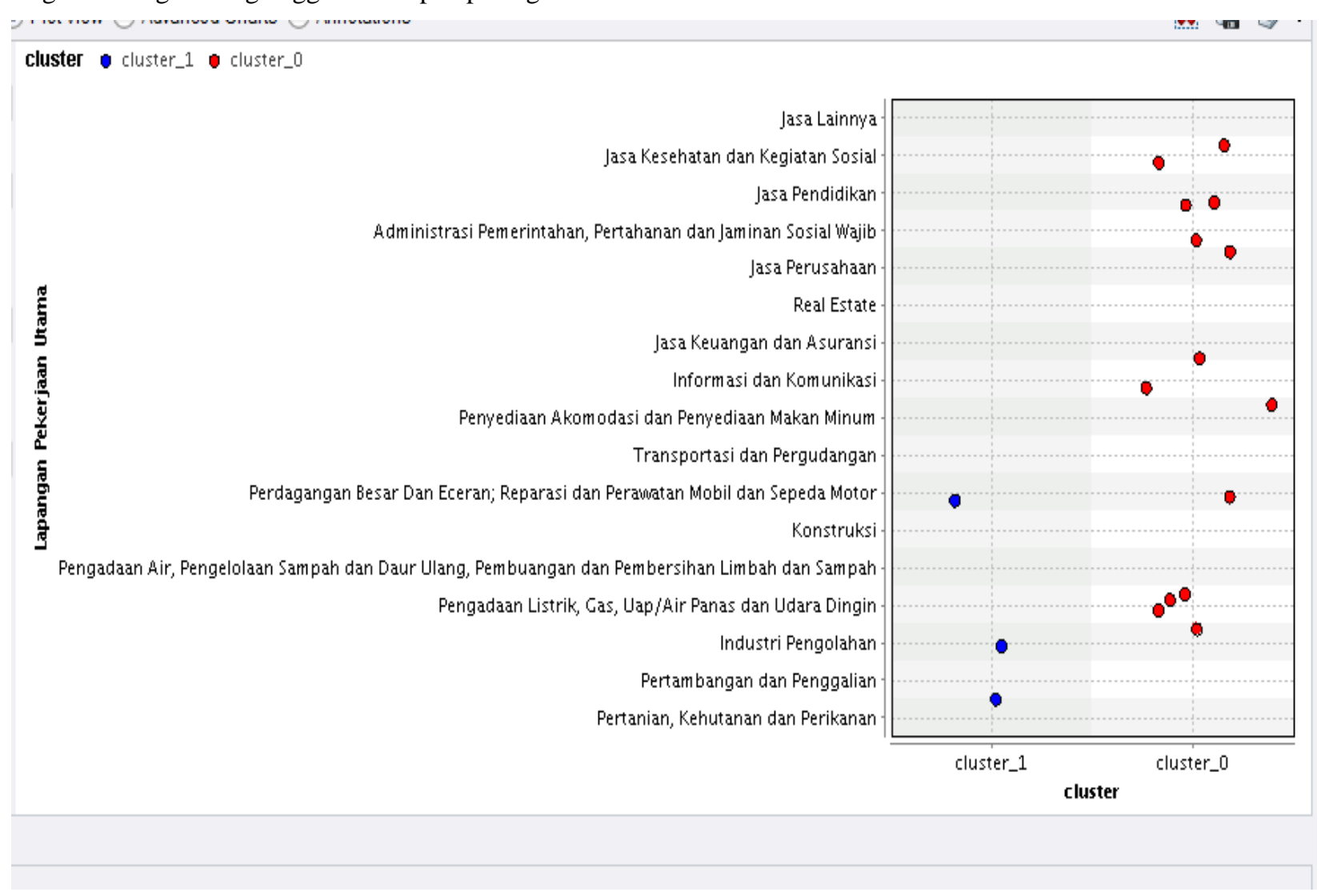

Gambar 2. Hasil Pengelompokan

Pada gambar 2 dapat dilihat bahwa terdapat 2 warna yang berbeda di mana cluster 1 berwarna biru dan cluster 0 berwarna merah.

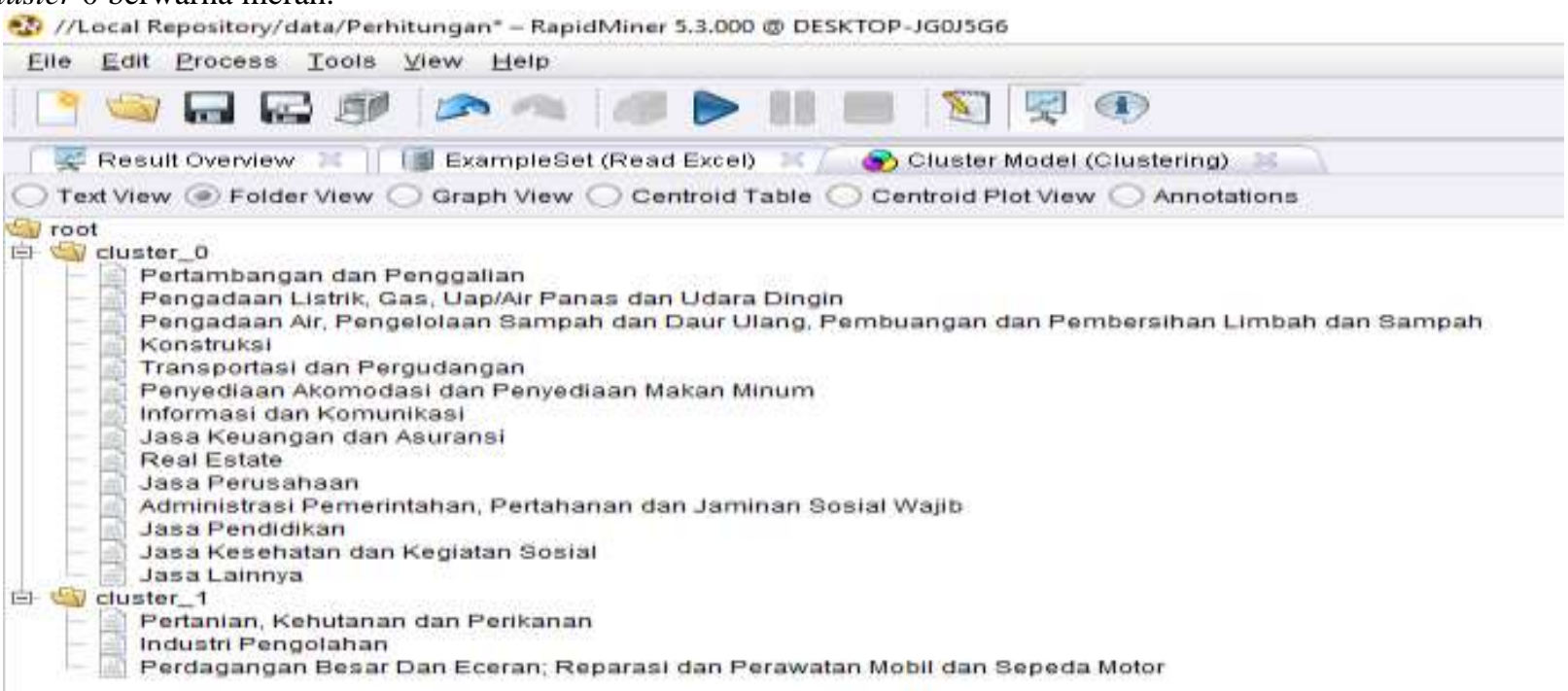


Dari gambar 3 dapat dilihat bahwa di peroleh 14 lapangan pekerjaan utama ( Pertambangan dan penggalian, Pengadaan listrik, gas, uap air panas dan udara dingin, pengadaan air, pengelolaan sampah, dan daur ulang, pembuangan dan pembersihan limbah dan sampah, Konstruksi, Transportasi dan pergudangan, Penyediaan akomodasi dan penyediaan makan minum, Jasa keuangan dan asuransi, Real estate, Jasa perusahaan, Administrasi pemerintahan, pertahanan, dan jaminan sosial wajib, Jasa pendidikan, Jasa kesehatan dan kegiatan sosial, dan Jasa lainnya) adalah cluster tinggi dan 3 lapangan pekerjaan utama ( Pertanian, perhutanan dan perikanan, Industri Pengolahan, Perdangan besar dan eceran, Reparasi dan perawatan mobil dan sepeda motor) adalah cluster rendah.

\section{KESIMPULAN}

Penerapan data mining dengan menggunakan metode $K$-Medoids dapat di terapkan, dengan bantuan aplikasi rapidminer 5.3. sebagai perhitungan perbandingannya, Dengan menggunakan 2 cluster yaitu, cluster tinggi dan cluster rendah di peroleh cluster tinggi sebanyak 3 lapangan pekerjaan utama (Pertanian, perhutanan dan perikanan, Industri Pengolahan, Perdangan besar dan eceran, Reparasi dan perawatan mobil dan sepeda motor). Dan cluster rendah sebanyak 14 lapangan pekerjaan utama (Pertambangan dan penggalian, Pengadaan listrik, gas, uap air panas dan udara dingin, pengadaan air, pengelolaan sampah, dan daur ulang, pembuangan dan pembersihan limbah dan sampah, Konstruksi, Transportasi dan pergudangan, Penyediaan akomodasi dan penyediaan makan minum, Jasa keuangan dan asuransi, Real estate, Jasa perusahaan, Administrasi pemerintahan, pertahanan, dan jaminan sosial wajib, Jasa pendidikan, Jasa kesehatan dan kegiatan sosial, dan Jasa lainnya). Sehingga masalah yang ada saat ini dapat meningkatkan kinerja pemerintah dalam mengatur penduduk dengan usia 15 tahun ke atas menurut lapangan pekerjaan utama dengan cermat dan tepat, dan dapat menghasilkan pekerja yang berbakat.

\section{REFERENCES}

[1] A. Soleh, Masalah Ketenagakerjaan Dan Pengangguran Di Indonesia, J. Ilm. Cano Ekon., vol. 6, no. 2, pp. 83-92, 2017.

[2] S. Defiyanti and M. Jajuli, Optimalisasi K - Medoid Dalam Pengklasteran Mahasiswa Pelamar Beasiswa Dengan Cubic Clustering Criterion, vol. 3, no. 1, pp. 211-218, 2017.

[3] A. P. Windarto, Implementation of Data Mining on Rice Imports by Major Country of Origin Using Algorithm Using KMeans Clustering Method, Int. J. Artif. Intell. Res., vol. 1, no. 2, pp. 26-33, 2017.

[4] D. F. Pramesti, M. T. Furqon, and C. Dewi, Implementasi Metode K-Medoids Clustering Untuk Pengelompokan Data Potensi Kebakaran Hutan / Lahan Berdasarkan Persebaran Titik Panas ( Hotspot ), J. Pengemb. Teknol. Inf. dan Ilmu Komput., vol. 1, no. 9, 2017.

[5] H. Zayuka, S. M. Nasution, Y. Purwanto, F. T. Elektro, and U. Telkom, Perancangan Dan Analisis Clustering Data Menggunakan Metode K-Medoids Untuk Berita Berbahasa Inggris Design and Analysis of Data Clustering Using K-Medoids Method, vol. 4, no. 2, pp. 2182-2190, 2017. 